\title{
Hydration Energies of Deprotonated Amino Acids from Gas Phase Equilibria Measurements
}

\author{
Henryk Wincel \\ Institute of Physical Chemistry, Polish Academy of Sciences, Warsaw, Poland
}

Singly hydrated clusters of deprotonated amino acids were studied using an electrospray high-pressure mass spectrometer equipped with a pulsed ion-beam reaction chamber. Thermochemical data, $\Delta H^{o}, \Delta S^{o}$, and $\Delta G^{o}$, for the hydration reaction [AA $\left.-\mathrm{H}\right]^{-}+\mathrm{H}_{2} \mathrm{O}=[\mathrm{AA}-$ $\mathrm{H}]^{-} \cdot\left(\mathrm{H}_{2} \mathrm{O}\right)$ were obtained from gas-phase equilibria determinations for AA = Gly, Ala, Val, Pro, Phe, Lys, Met, Trp, Gln, Arg, and Asp. The hydration free-energy changes are found to depend significantly on the side-chain substituents. The water binding energy in [AA $\mathrm{H}]^{-} \cdot\left(\mathrm{H}_{2} \mathrm{O}\right)$ increases with the gas-phase acidity of AA. The anionic hydrogen bond strengths in [AA $-\mathrm{H}^{-} \cdot\left(\mathrm{H}_{2} \mathrm{O}\right)$ are compared with those of the cationic bonds in the corresponding $\mathrm{AAH}^{+} \cdot\left(\mathrm{H}_{2} \mathrm{O}\right)$ systems. (J Am Soc Mass Spectrom 2008, 19, 1091-1097) (c) 2008 American Society for Mass Spectrometry

$\Lambda$ mino acid chemistry has been the subject of considerable attention during the past years because of its importance in understanding biological processes in living systems. In aqueous media at neutral $\mathrm{pH}$, most of the naturally occurring amino acids exist in zwitterionic form, where the amino group at the $\mathrm{N}$-terminus is usually protonated and the carboxylic group at the C-terminus is deprotonated. These groups are expected to interact with surrounding water, which is an integral part of a functioning biological system. Water molecules are directly involved in noncovalent interactions that play a central role in determining the structure and properties of macromolecules in living systems. Understanding these low-energy interactions is especially important because they provide a key to the secrets of cellular function in living organisms at the molecular level. Although most amino acids (AAs) in the gas phase exhibit a nonionic form, noncovalent interactions of their charged groups $\left(\mathrm{H}_{3} \mathrm{~N}^{+}-\right.$ and $-\mathrm{CO}_{2}^{-}$) with solvent molecules can be investigated separately by mass spectrometry after ion extraction from the solution into the gas-phase [1]. Studies of noncovalent interactions in hydrated gas-phase amino acid ions can provide detailed information about these interactions that is not available from solution studies, such as thermodynamic information for the binding energies of individual water molecules.

Most of the experimental and theoretical studies reported to date have focused on interactions of water molecules with protonated [2-15] and alkali-metal cationized amino acids $[9,16-29]$. It is established that side

Address reprint requests to Dr. H. Wincel, Institute of Physical Chemistry, Polish Academy of Sciences, Kasprzaka 44/52, 01-224 Warsaw, Poland. E-mail: wincel@ichf.edu.pl chains have a significant influence on the water binding energy to these cations [12, 13, 21, 28, 29].

While interactions of various organic molecules containing the carboxylate group $\left(-\mathrm{CO}_{2}^{-}\right)$with water molecules have been the subject of numerous studies [3034], very little research is available on hydration of deprotonated amino acids and peptides. Bowers and coworkers $[8,35]$ used an electrospray mass spectrometer equipped with a high-pressure drift cell to examine the interactions of deprotonated aspartic acid and deprotonated small peptides, such as dialanine and diglycine, with water. Degtyarenko et al. [36] employed ab initio molecular dynamic simulation to study the first hydration shell around charged groups $\left(\mathrm{H}_{3} \mathrm{~N}^{+}\right.$and $\mathrm{CO}_{2}^{-}$) of an L-alanine in a droplet of water.

This study presents the thermochemical properties for the hydration of a number of gas-phase deprotonated amino acids, $[\mathrm{AA}-\mathrm{H}]^{-}$, obtained from equilibrium experiments. The work is a continuation of previous studies on the hydration of protonated $[12,13]$ and cationized $[28,29]$ biomolecules in the gas phase.

\section{Experimental}

The experiments were performed with a high-pressure (HP) mass spectrometer using a pulsed ion-beam ESI ion source (Figure 1), which has been described in detail elsewhere [12]. Briefly, the reactant ions were obtained by electrospray from a silica capillary (ESC, $15 \mu \mathrm{m}$ i.d., $150 \mu \mathrm{m}$ o.d.) to which a negative voltage of $4 \mathrm{kV}$ was applied. A solution containing $\sim 2.0 \mathrm{mM}$ the sample in methanol was supplied to the capillary by a syringe pump at a rate of $0.8 \mu \mathrm{L} / \mathrm{min}$. The clustered ions were desolvated by a dry nitrogen gas counter current and in a heated pressure reducing capillary (PRC) through 


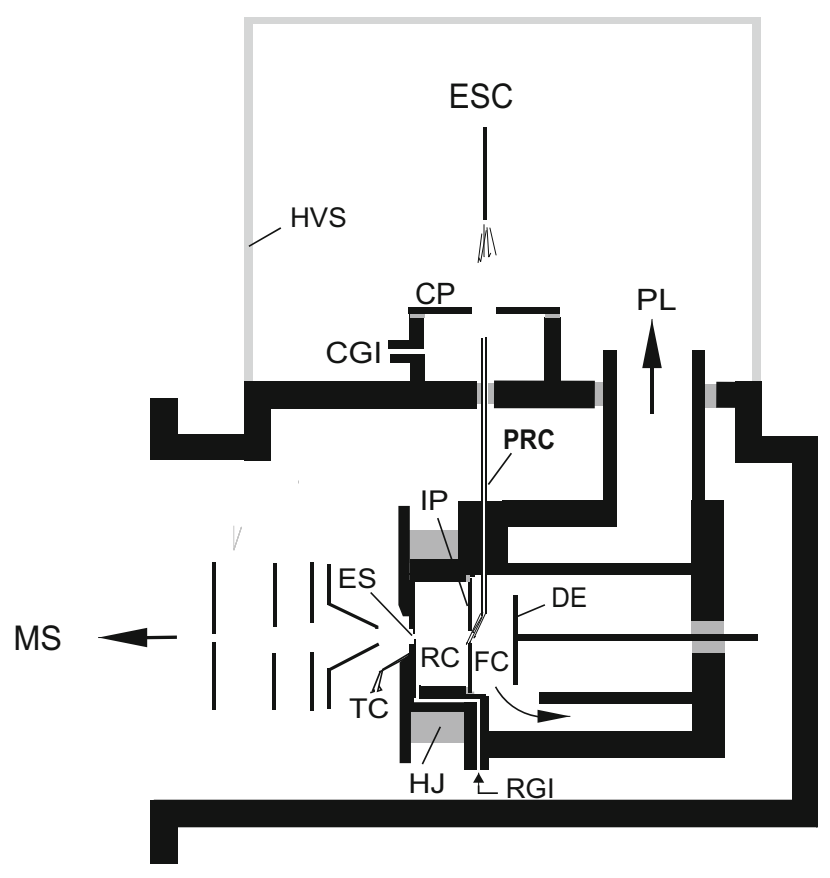

Figure 1. Scheme of the high-pressure ion source with pulsed ion beam: (ESC) electrospray capillary; (HVS) high voltage shield; (CP) curtain plate; (CGI) curtain gas inlet; (PL) pumping lead; (PRC) pressure reducing capillary; (FC) fore-chamber; (DE) deflection electrode; (IP) interface plate; (RC) reaction chamber; (RGI) reaction gas inlet; (TC) thermocouple; (ES) ion exit slit; $(\mathrm{HJ})$ electrically heated jacket.

which they were introduced into the fore-chamber (FC), and then deflected toward a $3 \mathrm{~mm}$ orifice in the interface plate (IP) leading to the reaction chamber (RC). Ions drifting across the RC toward the exit slit (ES) under the influence of a weak electric field $(2 \mathrm{~V} / \mathrm{cm}$ at 10 mbar) were hydrated and reached equilibrium before being sampled to the mass analysis section of the mass spectrometer.

Mass spectra were registered with continuous ion sampling, while for equilibrium determination the ion beam was injected into the RC in a pulsing mode by applying short pulses $(-46 \mathrm{~V}, 60 \mu \mathrm{s})$ to the deflection electrode (DE). The latter mode of operation allows for measurements of the arrival time distribution (ATD) of the ions across the RC.

The reagent gas mixture consisting of pure $\mathrm{N}_{2}$ as the carrier gas at about $10 \mathrm{mbar}$ and a known partial pressure of water vapor (0.1-0.25 mbar) was supplied to the RC via the heated reactant gas inlet (RGI) at a flow rate of $\sim 100 \mathrm{~mL} / \mathrm{min}$. The pressure was measured with an MKS capacitance manometer attached near the inlet of the RGI. The RC temperature was monitored by an iron-constantan thermocouple (TC), which was embedded close to the ion exit slit; the temperature can be varied from ambient to $\sim 300{ }^{\circ} \mathrm{C}$ by electrical heaters.

\section{Chemicals}

The amino acids were obtained from Aldrich Chemical Co. (Steinheim, Germany). $\mathrm{CH}_{3} \mathrm{OH}$ was purchased from Chempur (Piekary Slaskie, Poland). The water was deionized with a Millipore purifier, type Elix 5 (Vienna, Austria).

\section{Results and Discussion}

\section{General Description of Results}

Electrospray ionization of amino acids and dipeptides in the negative ion mode produces both deprotonated monomers, $[\mathrm{AA}-\mathrm{H}]^{-}$, and dimers, $[\mathrm{AA}-\mathrm{H}]^{-} \cdot \mathrm{AA}$. In the $\mathrm{RC}$, where no neutral $\mathrm{AA}$ is present, the equilibria for the hydration of $[\mathrm{AA}-\mathrm{H}]^{-}$have been dealt with in the following processes:

$$
\begin{aligned}
& {[\mathrm{AA}-\mathrm{H}]^{-}+\mathrm{H}_{2} \mathrm{O} \Leftrightarrow[\mathrm{AA}-\mathrm{H}]^{-} \cdot\left(\mathrm{H}_{2} \mathrm{O}\right)} \\
& {[\mathrm{AA}-\mathrm{H}]^{-} \cdot \mathrm{AA} \rightarrow[\mathrm{AA}-\mathrm{H}]^{-}+\mathrm{AA}}
\end{aligned}
$$

At water partial pressures of $0.1-0.2$ mbar, at which the present experiments were performed, the forward rates of reaction (1) are expected to proceed at the Langevin collision rate $\left(k_{f} \approx 10^{-9}\right.$ molecule $\left.\mathrm{cm}^{3} \mathrm{~s}^{-1}\right)$ and the reaction frequency is $k_{f}\left[\mathrm{H}_{2} \mathrm{O}\right] \approx 5 \times 10^{6} \mathrm{~s}^{\times 1}$. This rate is several orders of magnitude greater than the dissociation rates of $\left[(\mathrm{Gly})_{2}-\mathrm{H}\right]^{-} \cdot(\mathrm{Gly})_{2}$ and $\left[(\mathrm{Ala})_{2}-\mathrm{H}\right]^{-}$. $(\mathrm{Ala})_{2}$ reaction (2), obtained using Arrhenius activation parameters of $E_{\mathrm{a}}=32.2 \mathrm{kcal} / \mathrm{mol}$ and $A=10^{17} \mathrm{~s}^{-1}$ measured by Bowers et al. [35] for $\left[(\mathrm{Gly})_{2}-\mathrm{H}\right]^{-}$. $(\mathrm{Gly})_{2}$. These factors indicate that the product ions from reaction (2) should be sufficiently repopulated to establish equilibrium in reaction (1). Equilibrium attainment was checked by comparing the ATDs of the reactant and product ions (eq 1). The ions drifting through the $\mathrm{RC}$ to the exit slit undergo many switching reactions and their apparent mobilities should be equal. When equilibrium between two ions is established, their ATDs overlap (except for the scaling factor of the peak amplitude). This is illustrated in Figure 2 for the pair $[\mathrm{Val}-\mathrm{H}]^{-}$and $[\mathrm{Val}-\mathrm{H}]^{-} \cdot\left(\mathrm{H}_{2} \mathrm{O}\right)$, and inset (a) of the figure shows that the normalized ATDs are the same. Also, inset (b) demonstrates that within the error limits and the limits of statistical noise, the ratio of $[\text { Val }-\mathrm{H}]^{-} /[\mathrm{Val}-\mathrm{H}]^{-} \cdot\left(\mathrm{H}_{2} \mathrm{O}\right)$ remains essentially constant. These data imply that the system is at equilibrium under the present experimental conditions.

\section{Determination of Thermodynamic Properties}

The enthalpy $\left(\Delta H^{o}\right)$ and entropy $\left(\Delta S^{o}\right)$ changes were determined from temperature-dependent studies of the equilibrium constants $K_{e q}$ using the van't Hoff equation

$$
\text { 1n } K_{\text {eq }}=\left(\Delta S^{0} / R\right)-\left(\Delta H^{0} / R T\right)
$$

The equilibrium constants for the standard state pressure of 1000 mbar were obtained from the expression 


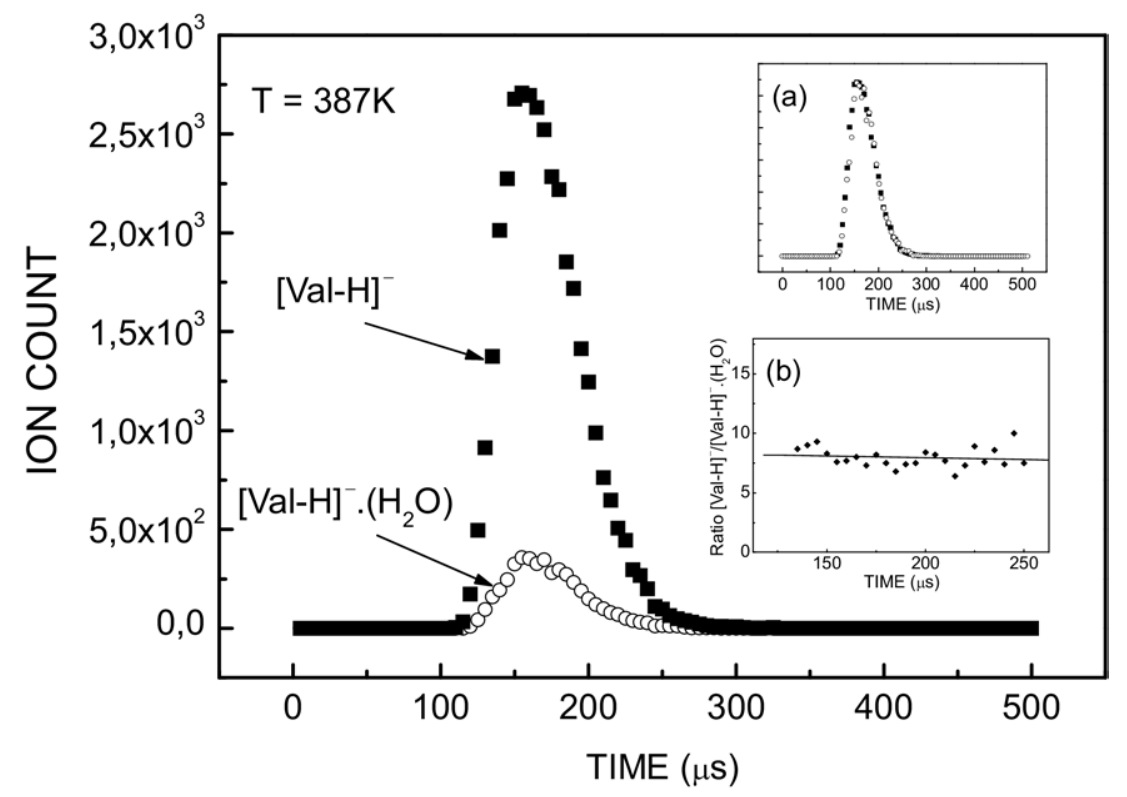

Figure 2. Arrival time distributions of the reactant $[\mathrm{Val}-\mathrm{H}]^{-}$, and product $[\mathrm{Val}-\mathrm{H}]^{-} \cdot\left(\mathrm{H}_{2} \mathrm{O}\right)$, ions. The insets show: (a) normalized at maximum; (b) ion intensities ratio of [Val $-\mathrm{H}]^{-} /\left[\mathrm{Val}-\mathrm{H}^{-}\left(\mathrm{H}_{2} \mathrm{O}\right)\right.$ as a function of ion arrival time.

$$
K_{e q}=\left(I_{n} \cdot 1000 / I_{n-1} \cdot P\right)
$$

where $I_{n}$ and $I_{n-1}$ are recorded ATD peak areas of $[\mathrm{AA}-\mathrm{H}]^{-} \cdot\left(\mathrm{H}_{2} \mathrm{O}\right)$ and $[\mathrm{AA}-\mathrm{H}]^{-}$, respectively, and $P$ is the known partial pressure of the water (in mbar).

The results of measured equilibrium constants as functions of temperature for the systems studied are presented in the form of van't Hoff plots in Figure 3. All data in the van't Hoff plots are linear and no bending can be distinguished within the experimental scatter. The weighted least-squares fitting procedure was used to obtain both the slopes and intercepts of each line. In this way the $\Delta H^{o}$ and $\Delta S^{o}$ values for hydration reactions (1) were determined, respectively. The values listed in Table 1 are the averages of at least three measurements and the error limits show the statistical fluctuations. Systematic error may be present and the absolute error could be considerably larger. The free-energy changes $\left(\Delta G^{o}\right)$ were obtained from $\Delta G^{o}=\Delta H^{o}-T \cdot \Delta S^{o}$. We determined the thermodynamic data for hydration of $\mathrm{CH}_{3} \mathrm{CO}_{2}^{-}$for comparison with mea-

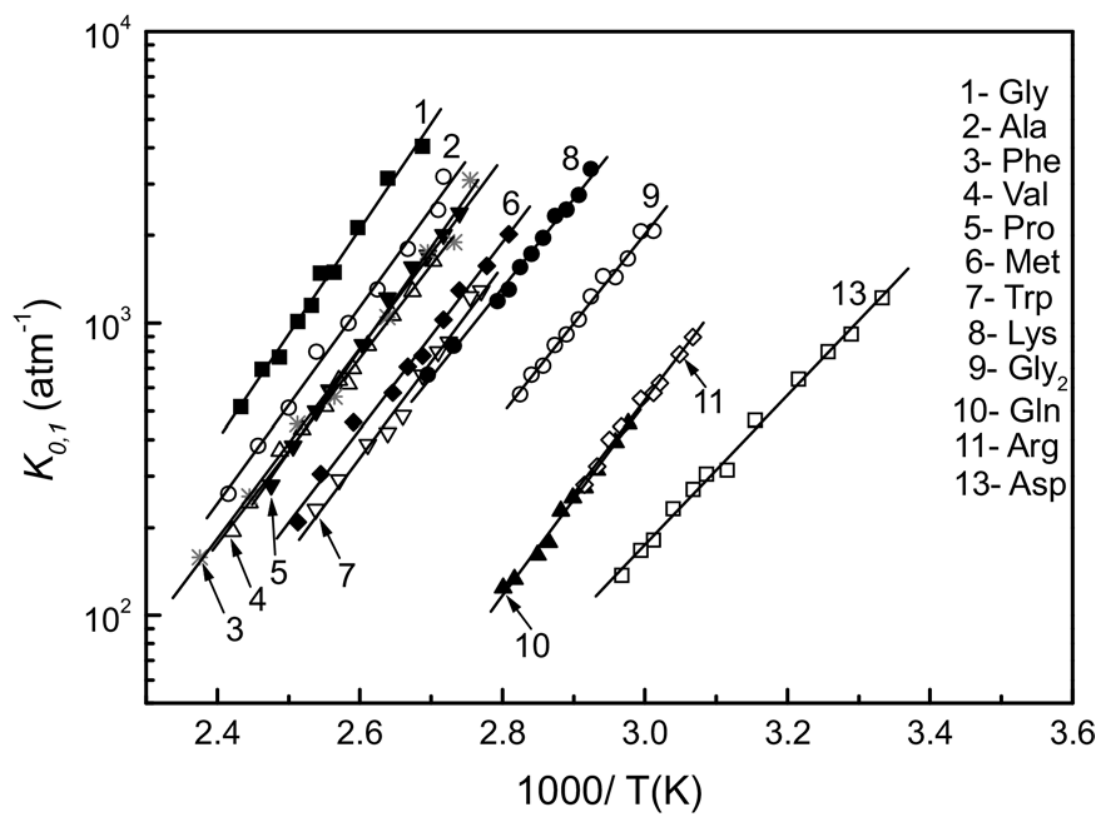

Figure 3. van't Hoff plots of equilibrium constants for the gas-phase reactions [AA $-\mathrm{H}]^{-}+\mathrm{H}_{2} \mathrm{O}=$ $[\mathrm{AA}-\mathrm{H}]^{-} \cdot\left(\mathrm{H}_{2} \mathrm{O}\right)$. Compounds AA are given in the figure. 
Table 1. Experimental enthalpies, entropies, and free energies for the hydration of deprotonated acetic acid, amino acids and dipeptides $^{a}$

\begin{tabular}{|c|c|c|c|c|}
\hline Ion & $-\Delta H_{n}^{o}(\mathrm{kcal} / \mathrm{mol})$ & $\Delta S_{n}^{o}(\mathrm{cal} / \mathrm{mol} \mathrm{K})$ & $-\Delta G_{n}^{o}(\mathrm{kcal} / \mathrm{mol})^{\mathrm{b}}$ & Ref. \\
\hline \multirow[t]{3}{*}{$\mathrm{CH}_{3} \mathrm{COO}_{2}^{-}$} & $16.4(0.8)$ & $25.4(2)$ & $9.0(1.4)$ & \\
\hline & $16.0(1.0)$ & 22.5 & $9.3(1.6)^{\mathrm{c}}$ & [31] \\
\hline & $16.4(1.5)$ & $\sim 24$ & $9.4(0.3)^{\mathrm{c}}$ & [33] \\
\hline$[\mathrm{Gly}-\mathrm{H}]^{-}$ & $16.0(0.3)$ & $26.6(0.4)$ & $8.2(0.4)$ & \\
\hline$[\mathrm{Ala}-\mathrm{H}]^{-}$ & $15.3(0.4)$ & $25.6(1.2)$ & $7.8(0.8)$ & \\
\hline$[\text { Pro-H }]^{-}$ & $15.4(0.5)$ & $26.5(1.5)$ & $7.6(0.9)$ & \\
\hline$\left[\right.$ Val-H] ${ }^{-}$ & $14.3(0.4)$ & $24.2(1.0)$ & $7.2(0.7)$ & \\
\hline [Lys-H] $^{-}$ & $14.5(0.6)$ & $25.0(1.3)$ & $7.2(1.0)$ & \\
\hline$[\text { Phe-H }]^{-}$ & $14.5(0.4)$ & $25.0(1.6)$ & $7.2(0.9)$ & \\
\hline$[\text { Met-H] }]^{-}$ & $14.5(0.5)$ & $25.3(1.0)$ & $7.1(0.8)$ & \\
\hline$[\text { Trp-H] }]^{-}$ & $14.8(0.5)$ & $26.9(1.4)$ & $6.9(0.9)$ & \\
\hline$[\mathrm{Gln}-\mathrm{H}]^{-}$ & $14.4(0.4)$ & $30.8(1.2)$ & $5.4(0.8)$ & \\
\hline$[\text { Arg-H }]^{-}$ & $15.1(0.5)$ & $33.0(1.4)$ & $5.4(0.9)$ & \\
\hline \multirow[t]{2}{*}[\text{Asp-H}]{$^{-}$} & $12.3(0.5)$ & $27.0(1.9)$ & $4.4(1.1)$ & \\
\hline & $9.2(0.3)^{\mathrm{c}}$ & & & [8] \\
\hline \multirow[t]{2}{*}[(\mathrm{Gly})_{2}-\mathrm{H}]{$^{-}$} & $14.5(0.7)$ & $27.5(1.5)$ & $6.5(1.1)$ & \\
\hline & $\begin{array}{c}11.0(0.3)^{\mathrm{c}} \\
15.8^{\mathrm{d}}\end{array}$ & $14.5(0.7)^{\mathrm{c}}$ & $6.8(0.5)$ & [35] \\
\hline$\left[(\mathrm{Ala})_{2}-\mathrm{H}\right]^{-}$ & $\begin{array}{c}11.7(0.2)^{\mathrm{c}} \\
15.6^{\mathrm{d}}\end{array}$ & $17.1(0.4)^{\mathrm{c}}$ & $6.7(0.3)$ & [35] \\
\hline
\end{tabular}

Standard pressure is 1000 mbar.

aErrors are listed in parentheses.

${ }^{\mathrm{b}} \Delta G^{O}$ at $293 \mathrm{~K}$.

'Using high-pressure mass spectrometry.

dBinding energy calculated with density functional theory [35].

surements from other laboratories [31, 33]. As shown in Table 1, these values are in reasonable agreement with those obtained in other experiments.

The present $\Delta H^{o}$ value for [Asp $\left.-\mathrm{H}\right]^{-} \cdot\left(\mathrm{H}_{2} \mathrm{O}\right)$ is significantly higher than that measured by Bowers and coworkers [8]. For [(Gly $\left.)_{2}-\mathrm{H}\right]^{-} \cdot\left(\mathrm{H}_{2} \mathrm{O}\right)$, both $\Delta H^{o}$ and $\Delta S^{o}$ values obtained in the present work are also substantially higher than those experimentally determined by Bowers et al. [35], but the $\Delta G^{o}$ values are in good agreement. The water binding energy calculated by these authors for $\left[(\mathrm{Gly})_{2}-\mathrm{H}\right]^{-} \cdot\left(\mathrm{H}_{2} \mathrm{O}\right)$ agrees reasonably well with the hydration enthalpy $\left(\Delta H^{o}\right)$ of the present work, Table 1.

\section{Hydration and Structural Information}

As can be seen from Table 1, for all the deprotonated AAs under investigation, the hydration enthalpies are approximately the same and close to that of $\mathrm{CH}_{3} \mathrm{CO}_{2}-$, with the exception of [Asp $-\mathrm{H}]^{-}$. These AAs are expected to be ionized via deprotonation of the carboxyl group, and similar solvation of the carboxyl group for each of these anions is consistent with their similar hydration enthalpies.
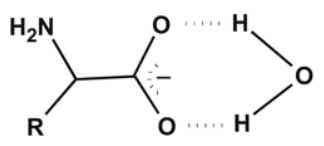

$\mathbf{R}=$ side chain

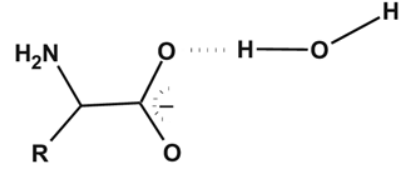

2

The $\Delta S^{o}$ values for the hydrates of [Gly $\left.-\mathrm{H}\right]^{-}$, $[\mathrm{Ala}-\mathrm{H}]^{-}$, $\left[\mathrm{Pro}-\mathrm{H}^{-}\right.$, $\left[\mathrm{Val}-\mathrm{H}^{-}\right.$, $[\mathrm{Phe}-\mathrm{H}]^{-}$, [Lys $\mathrm{H}]^{-}$, $[\text {Met }-\mathrm{H}]^{-}$, and $[\operatorname{Trp}-\mathrm{H}]^{-}$are similar within the experimental error limits (Table 1). This finding is also consistent with the same modes of water coordination in these hydrates. The favorable geometry for these systems, based on calculations for $\mathrm{HCO}_{2}^{-.}\left(\mathrm{H}_{2} \mathrm{O}\right)$ [30], and $\left[(\mathrm{Ala})_{2}-\mathrm{H}\right]^{-} \cdot\left(\mathrm{H}_{2} \mathrm{O}\right)$ [35], is expected to be a doubly hydrogen-bonded structure such as $\mathbf{1}$. The doubly hydrogen-bonded structure is more stable, by $\sim 3$ $\mathrm{kcal} / \mathrm{mol}$, than the singly bonded one, 2 [35].

For the $[\mathrm{Gln}-\mathrm{H}]^{-} \cdot\left(\mathrm{H}_{2} \mathrm{O}\right)$ and $[\mathrm{Arg}-\mathrm{H}]^{-} \cdot\left(\mathrm{H}_{2} \mathrm{O}\right)$ complexes, we obtain greater $-\Delta S^{o}$ values than those for the systems discussed above (see Table 1), implying a loss in the freedom of $\mathrm{H}_{2} \mathrm{O}$ motion in these complexes. This observation can be rationalized by the fact that in both cases, beside the amino group, the side chains have active sites (O and $\mathrm{NH}$, respectively), which interact with $\mathrm{H}_{2} \mathrm{O}$ with the formation of an intermolecular hydrogen bonding structure such as those shown schematically below, $\mathbf{3}$ and $\mathbf{4}$.

In the case of $[\mathrm{Asp}-\mathrm{H}]^{-}$, the relatively low value of $-\Delta H^{0}$ can be attributed to the formation of cyclic

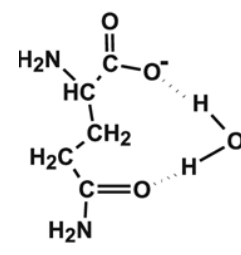

3

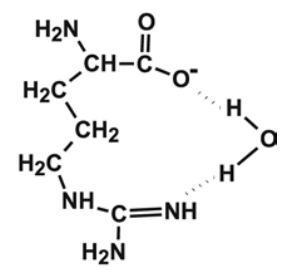

4 


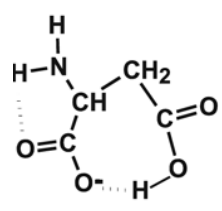

5

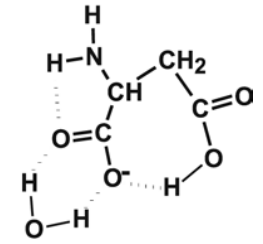

$5 \mathbf{a}$ conformation via the $\mathrm{O}-\mathrm{H} \ldots \mathrm{O}^{-}$intramolecular hydrogen bond. Theoretical calculations [38, 39] clearly show that aspartic acid forms an anion with the lowest energy and a strong hydrogen-bonded ring structure between the main chain $\mathrm{CO}^{-}{ }_{2}$ and the $\mathrm{CO}_{2} \mathrm{H}$ side-chain groups, as illustrated above, $\mathbf{5}$. Such bonds exhibit bond energies in the range of $14-28 \mathrm{kcal} / \mathrm{mol}$ [40].

The hydrogen-bonded cyclization stabilizes the ionic reactant and weakens the intermolecular hydrogen bonding interaction between the $\mathrm{H}_{2} \mathrm{O}$ molecule and the $\mathrm{CO}_{2}^{-}$group, $5 \mathbf{a}$, due to the charge delocalization on the solvating group. This effect is evident when the hydration free-energy $\left(-\Delta G^{o}\right)$ of $4.5 \mathrm{kcal} / \mathrm{mol}$ for $[\mathrm{Asp}-\mathrm{H}]^{-}$ is compared to that for [Ala $-\mathrm{H}]^{-}(7.8 \mathrm{kcal} / \mathrm{mol})$ or $[\mathrm{Va}$ $-\mathrm{H}]^{-}(7.2 \mathrm{kcal} / \mathrm{mol})$, Table 1.

A similar situation is also observed for both the deprotonated dicarboxylic acids, $\mathrm{HCO}_{2}-\left(\mathrm{CH}_{2}\right)_{n}-\mathrm{CO}_{2}^{-}$ [33], and the protonated alkane diamines, $\mathrm{H}_{2} \mathrm{~N}-$ $\left(\mathrm{CH}_{2}\right)_{n} \mathrm{NH}_{3}^{+}$[2], where cyclization with the formation of internal strong hydrogen bonding has been shown to occur. For example, the $-\Delta G^{o}=5.4 \mathrm{kcal} / \mathrm{mol}$ [33] for the hydration of succinic acid, $\mathrm{HCO}_{2}-\left(\mathrm{CH}_{2}\right)_{2}-\mathrm{CO}_{2}^{-}$, is much lower than that of $9.3 \mathrm{kcal} / \mathrm{mol}$ [33] for propionic acid, $\mathrm{C}_{2} \mathrm{H}_{5} \mathrm{CO}_{2}^{-}$of comparable size. Similarly, the $-\Delta G^{o}$ value of $6.2 \mathrm{kcal} / \mathrm{mol}$ [2] obtained for $\mathrm{NH}_{2}\left(\mathrm{CH}_{2}\right)_{3} \mathrm{NH}_{3}^{+}$is smaller than that of $8.8 \mathrm{kcal} / \mathrm{mol}$ [41] for $\mathrm{n}-\mathrm{C}_{3} \mathrm{H}_{7} \mathrm{NH}_{3}^{+}$.

\section{Correlation Between Hydration Free Energies and Acidities}

As shown in Table 1, the side chains have a significant effect on water binding energies to $[\mathrm{AA}-\mathrm{H}]^{-}$. A plot of the hydration free energies versus the corresponding gas-phase acidities $\left(\Delta H_{a c}^{o}\right)$ of AAs obtained experimentally by Poutsma et al. [38] is shown in Figure 4.

A linear correlation exists between the $-\Delta G^{o}$ values and the corresponding $\Delta H_{a c}^{o}$. An analogous correlation was previously obtained by Kebarle and coworkers [33] for a series of singly hydrated anions of the carboxylic acids and some oxo acids. This effect is attributed to the charge delocalization from the anionic sites by electron withdrawing groups, resulting in lower hydrogenbonding interactions with $\mathrm{H}_{2} \mathrm{O}$, dominated by electrostatics. The correlation between $\Delta G^{o}$ and $\Delta H_{a c}^{o}$ arises from the fact that the gas-phase acidity is thermochemically related to the electron affinity, $(E A)$, by eq 5 .

$$
\Delta H_{a c}^{o}=D(\mathrm{AA}-\mathrm{H})+I P(\mathrm{H})-E A([\mathrm{AA}-\mathrm{H}])
$$

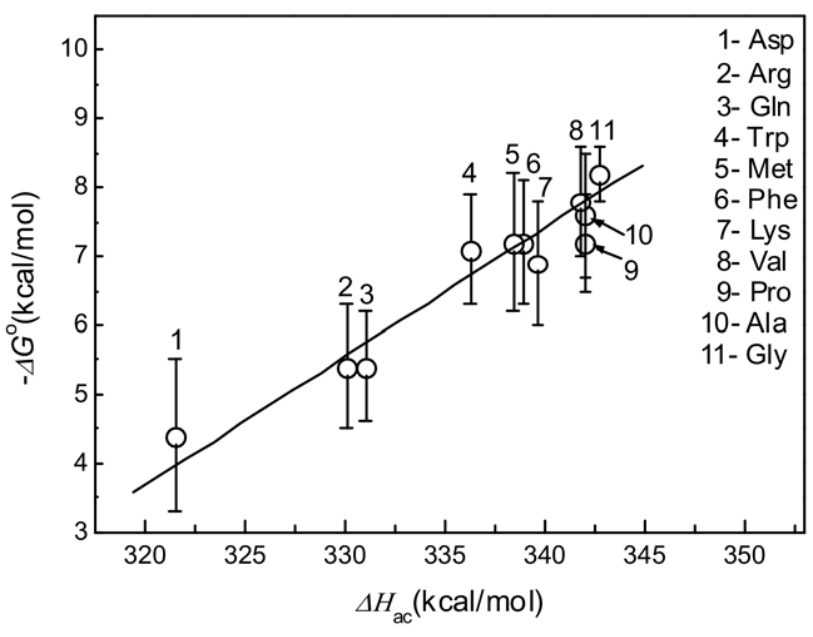

Figure 4. Plot of the hydration free energies, $-\Delta G^{o}$, at $293 \mathrm{~K}$ for the hydration of deprotonated amino acids, $[\mathrm{A}-\mathrm{H}]{ }^{-}$versus corresponding gas-phase acidity of AA, $\Delta H_{a c}^{o}$. The $\Delta H_{a c}^{o}$ values are taken from reference [38].

Since the ionization potential of hydrogen, $I P(\mathrm{H})=$ $313.6 \mathrm{kcal} / \mathrm{mol}$, is constant, and the bond strength in the carboxylic $\mathrm{CO}_{2} \mathrm{H}$ group is approximately constant, $D(\mathrm{O}-\mathrm{H}) \approx 106 \mathrm{kcal} / \mathrm{mol}$ [42], the electron affinity of the [AA $-\mathrm{H}$ ] radical is expected to be a key factor in determining the residual charge density on the $\mathrm{CO}_{2}^{-}$ group in $[\mathrm{AA}-\mathrm{H}]^{-}$anions.

In the $[\mathrm{AA}-\mathrm{H}]^{-} \cdot\left(\mathrm{H}_{2} \mathrm{O}\right)$ systems studied here, the electron withdrawing effect of the side-chain substituents is reflected in smaller $-\Delta G^{o}$ values for these complexes, Table 1 , in comparison to that of the simplest amino acid, [Gly $-\mathrm{H}]^{-} \cdot\left(\mathrm{H}_{2} \mathrm{O}\right)$. As can be seen from the table, the $-\Delta G^{o}$ values for these complexes follow the order [Gly $-\mathrm{H}]^{-}>[\mathrm{Ala}-\mathrm{H}]^{-}>[\mathrm{Pro}-\mathrm{H}]^{-}>[\mathrm{Val}$ $-\mathrm{H}]^{-} \approx[\text { Lys }-\mathrm{H}]^{-} \approx[\text { Phe }-\mathrm{H}]^{-}>[\text {Met }-\mathrm{H}]^{-}>$ $[\operatorname{Trp}-\mathrm{H}]^{-}>[\mathrm{Gln}-\mathrm{H}]^{-} \approx[\mathrm{Arg}-\mathrm{H}]^{-}>[\mathrm{Asp}-\mathrm{H}]^{-}$. This trend is consistent with the relative ordering of $\Delta H_{a c}^{o}$ recommended by Poutsma and coworkers [38]. Generally, the differences between the values of neighboring positions in the ordering of both $-\Delta G^{o}$ and $\Delta H_{a c}^{o}$ are within the experimental error.

\section{Comparison with Protonated Amino Acids}

A comparison between the anionic and cationic binding strengths is provided in Table 2 . With the exception of Lys, the $\Delta G^{o}$ values for [AA $\left.-\mathrm{H}\right]^{-} \cdot\left(\mathrm{H}_{2} \mathrm{O}\right)$ are similar within $2 \mathrm{kcal} / \mathrm{mol}$ or less to those for the corresponding complexes, $\mathrm{AAH}^{+} \cdot\left(\mathrm{H}_{2} \mathrm{O}\right)$. This confirms the electrostatic nature of water interaction with the anionic and cationic sites of AAs. Although the variation of the $\Delta G^{o}$ values with the nature of the AA displays a similar trend, small differences between the values for the corresponding complexes can be found, e.g., $\left[(\mathrm{Gly})_{2}-\right.$ $\mathrm{H}]^{-} \cdot\left(\mathrm{H}_{2} \mathrm{O}\right)$ versus $(\mathrm{Gly})_{2} \mathrm{H}^{+} \cdot\left(\mathrm{H}_{2} \mathrm{O}\right)$ and $\left[(\mathrm{Ala})_{2}-\mathrm{H}\right]^{-}$ $\cdot\left(\mathrm{H}_{2} \mathrm{O}\right)$ versus $(\mathrm{Ala})_{2} \mathrm{H}^{+} \cdot\left(\mathrm{H}_{2} \mathrm{O}\right)$. These differences may indicate stronger $\mathrm{H}$-bonding interactions in both cat- 
Table 2. Free energies ${ }^{\mathrm{a}}$ of monohydration of deprotonated and protonated amino acids and dipeptides ${ }^{a}$

\begin{tabular}{|c|c|c|}
\hline AA & {$[\mathrm{AA}-\mathrm{H}]^{-}$} & $\mathrm{AAH}^{+}$ \\
\hline Gly & $8.2(0.4)$ & $9.4(1.2)^{\mathrm{b}} 9.7(0.3)^{\mathrm{c}}$ \\
\hline Ala & $7.8(0.8)$ & $8.8(0.5)^{b}$ \\
\hline Val & $7.2(0.7)$ & $7.8(0.8)^{d}$ \\
\hline Pro & $7.6(0.9)$ & $7.7(0.7)^{b}$ \\
\hline Phe & $7.2(0.9)$ & $7.6(0.8)^{b}$ \\
\hline Met & $7.1(0.8)$ & $7.2(0.9)^{d}$ \\
\hline Lys & $7.2(1.0)$ & $5.2(0.3)^{\mathrm{c}}$ \\
\hline Arg & $5.4(0.9)$ & $4.5^{\mathrm{e}}$ \\
\hline$(\mathrm{Gly})_{2}$ & $6.5(1.1) ; 6.8(0.5)^{f}$ & $8.8(0.3)^{\mathrm{c}}$ \\
\hline$(\mathrm{Ala})_{2}$ & $6.7(0.3)^{f}$ & $7.4(0.1)^{\mathrm{g}}$ \\
\hline
\end{tabular}

a Free energy change in $\mathrm{kcal} / \mathrm{mol}$, standard state $1000 \mathrm{mbar}$ at $293 \mathrm{~K}$. ${ }^{\mathrm{b}}$ Ref. [13].

${ }^{\mathrm{c}}$ Ref. [2].

${ }^{\mathrm{d}}$ Ref. [12].

eRef. [37].

fRef. [35].

${ }^{\text {gRef. [5]. }}$

ionic complexes, resulting from higher positive charge density concentrated on $-\mathrm{NH}_{3}^{+}$compared with a more diffusive negative charge on the $-\mathrm{CO}_{2}^{-}$group [8]. However, this explanation is inconsistent with findings for other anionic and cationic pairs for which the $\Delta G^{o}$ values are essentially the same (Table 2). Possibly in hydrated dipeptides the water molecule could also be involved in intramolecular $\mathrm{H}$-bonding interactions with the chains, and the observed differences in the $\Delta G^{o}$ values for these complexes may reflect the consequences of this effect.

The greater $-\Delta G^{o}$ value found for [Lys $\left.-\mathrm{H}\right]^{-} \cdot\left(\mathrm{H}_{2} \mathrm{O}\right)$ than for $\mathrm{LysH}^{+} \cdot\left(\mathrm{H}_{2} \mathrm{O}\right)$ is attributable to the fact that $\mathrm{LysH}^{+}$forms a cyclic structure with an intramolecular hydrogen bond between the N-terminal amino group and the amine of the side chain [43]. As discussed above, the ions that form such internally H-bonded cyclic structures generally show weaker interactions with solvent molecules than those which form extended conformations.

\section{Conclusions}

Noncovalent interactions between the water molecule and deprotonated amino acids were investigated. The water binding energies in $[\mathrm{AA}-\mathrm{H}]^{-} \cdot\left(\mathrm{H}_{2} \mathrm{O}\right)$ complexes were obtained for 11 amino acids. The observations indicate a substantial effect of the side-chain substituents on the binding strengths in these complexes. A similar trend has been previously observed for protonated systems, $\mathrm{AAH}^{+} \cdot\left(\mathrm{H}_{2} \mathrm{O}\right)$. The data obtained from model systems provide a better understanding of the interaction between anionic and cationic sites of amino acids with water molecules.

\section{Acknowledgments}

The authors acknowledges support for this study by grant no. 3T09A02728 from the Ministry of Science and Higher Education, Poland.

\section{References}

1. Wyttenbach, T.; Bowers, M. T. Intramolecular Interactions in Biomolecular Systems Examined by Mass Spectrometry. Ann. Rev. Phys. Chem. 2007, 58, 511-533.

2. Klassen, J. S.; Blades, A. T.; Kebarle, P. Determinations of Ion-Molecule Equilibria Involving Ions Produced by Electrospray. Hydration of Protonated Amines, Diamines, and Some Small Peptides. J. Phys. Chem. 1995, 99, 15509-15517.

3. Woenckhaus, J.; Mao, Y.; Jarrold, M. F. Hydration of Gas Phase Proteins: Folded +5 and Unfolded +7 Charge States of cytochrome c. J. Phys. Chem. B 1997, 101, 847-851.

4. Woenckhaus, J.; Hudgins, R. R.; Jarrold, M. F. Hydration of Gas-Phase Proteins: A Special Hydration Site on Gas-Phase BPTI. J. Am. Chem. Soc. 1997, 119, 9586-9587.

5. Liu, D.; Wyttenbach, T.; Barran, P. E.; Bowers, M. T. Sequential Hydration of Small Protonated Peptides. J. Am. Chem. Soc. 2003, 125, 8458-8464.

6. Liu, D.; Wyttenbach, T.; Bowers, M. T. Hydration of Protonated Primary Amines: Effects of Intermolecular and Intramolecular Hydrogen Bonds. Int. J. Mass Spectrom. 2004, 236, 81-90.

7. $\mathrm{Ai}, \mathrm{H} . ; \mathrm{Bu}, \mathrm{Y}$. Reservation Energy Bonds and Structural Stability of Series of Multihydrated $\left(n \mathrm{H}_{2} \mathrm{O}=1-10\right)$ Glycine- $\mathrm{H}^{+} \mathrm{M}^{+}(\mathrm{M}=\mathrm{Li}, \mathrm{Na}$, or K) Complexes. J. Phys. Chem. B 2004, 108, 1241-1254.

8. Wyttenbach, T.; Liu, D.; Bowers, M. T. Hydration of Small Peptides. Int. J. Mass Spectrom. 2005, 240, 221-232.

9. Kamariotis, A.; Boyarkin, O. V.; Mercier, S. R.; Beck, R. D.; Bush, M. F.; Williams, E. R.; Rizzo, T. R. Infrared Spectroscopy of Hydrated Amino Acids in the Gas Phase: Protonated and Lithiated Valine. J. Am. Chem. Soc. 2006, 128, 905-916.

10. Rozman, M.; Srzic, D.; Klasinc, L. Gas-Phase Interaction of Protonated Lysine with Water. Int. J. Mass Spectrom. 2006, 253, 201-206.

11. Toyama, N.; Kohno, J.; Marun, F.; Kondow, T. Solvation Structure of Arginine in Aqueous Solution Studied by Liquid Beam Technique. Chem. Phys. Lett. 2006, 419, 369-373.

12. Wincel, H. Hydration of Gas-Phase Protonated Alkylamines, Amino Acids, and Dipeptides Produced by Electrospray. Int. J. Mass Spectrom. 2006, 251, 23-31.

13. Wincel, H. Hydration Energies of Protonated Amino Acids. Chem. Phys. Lett. 2007, 439, 157-161.

14. Michaux, C.; Wouters, J.; Jacquemin, D.; Perpète, E. A. A Theoretical Investigation of the Hydrated Glycine Cation Energetics and Structures. Chem. Phys. Lett. 2007, 445, 57-61.

15. Rozman, M. The Gas-Phase H/D Exchange Mechanism of Protonated Amino Acids. J. Am. Soc. Mass Spectrom. 2005, 16, 1846-1852.

16. Jockusch, R. A.; Lemoff, A. S.; Williams, E. R. Ion and Water Coordination on the Structure of a Gas-Phase Amino Acid. J. Am. Chem. Soc. 2001, 123, 12255-12265.

17. Jockusch, R. A.; Lemoff, A. S.; Williams, E. R. Hydration of ValineCation Complexes in the Gas Phase: On the Number of Water Molecules Necessary to Form a Zwitterion. J. Phys. Chem. A 2001, 105, 1092910942.

18. Lemoff, A. S.; Bush, M. F.; Williams, E. R. Binding Energies of Water to Sodiated Valine and Structural Isomers in the Gas Phase: The Effect of Proton Affinity on Zwitterion Stability. J. Am. Chem. Soc. 2003, 125, 13576-13584.

19. Lemoff, A. S.; Williams, E. R. Binding Energies of Water to Lithiated Valine: Formation of Solution-Phase Structure in Vacuo. J. Am. Soc. Mass Spectrom. 2004, 15, 1014-1024.

20. Lemoff, A. S.; Bush, M. F.; Williams, E. R. Structures of Cationized Proline Analogues: Evidence for the Zwitterionic Form. J. Phys. Chem. A 2005, 109, 1903-1910.

21. Lemoff, A. S.; Bush, M. F.; Wu, C.-C.; Williams, E. R. Structures and Hydration Enthalpies of Cationized Glutamine and Structural Analogues in the Gas Phase. J. Am. Chem. Soc. 2005, 127, 10276-10286.

22. Lemoff, A. S.; Wu, C.-C.; Bush, M. F.; Williams, E. R. Binding Energies of Water to Doubly Hydrated Cationized Glutamine and Structural Analogues in the Gas Phase. J. Phys. Chem. A 2006, 110, 3662-3669.

23. Lemoff, A. S.; Bush, M. F.; O'Brien, J. T.; Williams, E. R. Structures of Lithiated Lysine and Structural Analogues in the Gas Phase: Effects of Water and Proton Affinity on Zwitterionic Stability. J. Phys. Chem. A 2006, 110, 8433-8442.

24. Ye, S. J; Moision, R. M.; Armentrout, P. B. Sequential Bond Energies of Water to Sodium Glycine Cation. Int. J. Mass Spectrom. 2005, 240, 233-248.

25. Ye, S. J; Moision, R. M.; Armentrout, P. B. Sequential Bond Energies of Water to Sodium Proline Cation. Int. J. Mass Spectrom. 2006, 253, 288-304.

26. Remko, M.; Rode, B. M. Effect of Metal Ions $\left(\mathrm{Li}^{+}, \mathrm{Na}^{+}, \mathrm{K}^{+}, \mathrm{Mg}^{2+}, \mathrm{Ca}^{2+}\right.$ $\mathrm{Ni}^{2+}, \mathrm{Cu}^{2+}$, and $\mathrm{Zn}^{2+}$ ) and Water Coordination on the Structure of Glycine and Zwitterionic Glycine. J. Phys. Chem. A 2006, 110, 1960-1967.

27. Bush, M. F.; Prell, J. S.; Saykally, R. J.; Williams, E. R. One Water Molecule Stabilizes the Cationized Arginine Zwitterions. J. Am. Chem. Soc. 2007, 129, 13544-13553.

28. Wincel, H. Hydration Energies of Sodiated Amino Acids from GasPhase Equilibria Determinations. J. Phys. Chem. A 2007, 111, 5784-5791.

29. Wincel, H. Hydration of Potassiated Amino Acids in the Gas Phase. J. Am. Soc. Mass Spectrom. 2007, 18, 2083-2089. 
30. Gao, J; Garner, D. S.; Jorgensen W. J. Ab Initio Study of Structures and Binding Energies for Anion-Water Complexes. J. Am. Chem. Soc. 1986, $108,4784-4790$

31. Meot-Ner Mautner, M.; Sieck, L. The Ionic Hydrogen Bond and Ion Solvation. 5. OH-O ${ }^{-}$Bonds. Gas-Phase Solvation and Clustering of Alkoxide and Carboxylate Anions. I. Am. Chem. Soc. 1986, 108, 7525-7529.

32. Meot-Ner Mautner, M. Ionic Hydrogen Bond and Ion Solvation. 6 . Interaction Energies of the Acetate Ion with Organic Molecules. Comparison of $\mathrm{CH}_{3} \mathrm{COO}^{-}$with $\mathrm{Cl}^{-}, \mathrm{CN}^{-}$, and $\mathrm{SH}^{-}$. J. Am. Chem. Soc. 1988, $110,3854-3858$

33. Blades, A. T; Klassen, J. S.; Kebarle, P. Free Energies of Hydration in the Gas Phase of the Anions of Some Oxo Acids of C, N, S, P, Cl, and I. J. Am. Chem. Soc. 1995, 117, 10563-10571.

34. Viidanoja, J.; Reiner, T.; Kiendler, A.; Grimm, F.; Arnold, F. Laboratory Investigations of Negative Ion Molecule Reactions of Propionic, Butyric, Glyoxylic, Pyruvic, and Pinonic Acids. Int. J. Mass Spectrom. 2000, 194, 53-68.

35. Liu, D.; Wyttenbach, T.; Carpenter, C. J.; Bowers, M. T. Investigation of Noncovalent Interactions in Deprotonated Peptides: Structural and Energetic Competition Between Aggregation and Hydration J. Am. Chem. Soc. 2004, 126, 3261-3270.

36. Degtyarenko, I. M.; Jalkannen, K. J.; Gurtovenko, A. A.; Nieminen, R. M L-Alanine in a Droplet of Water: A Density-Functional Molecular Dynamics Study. J. Phys. Chem. B 2007, 111, 4227-4234.
37. Wyttenbach, T.; Bowers, M. T. Gas-Phase Conformations: The Ion Mobility/Ion Chromatography Method. Top. Curr. Chem. 2003, 225, 207-232.

38. Jones, C. M.; Bernier, M.; Carson, E.; Colyer, K. E.; Metz, R.; Pawlow, A.; Wischow, E. D.; Webb, I.; Andriole, E. J: Poutsma, J. C. Gas-Phase Acidities of the 20 Protein Amino Acids. Int. J. Mass Spectrom. 2007, 267 54-62.

39. Li, Z.; Matus, M. H.; Velazquez, H. A.; Dixon, D. A.; Casady, C. J.; Gas-Phase Acidities of Aspartic Acid, Glutamic Acid, and Their Amino Acid Amides. Int. J. Mass Spectrom. 2007, 265, 213-223.

40. Bach, R. D.; Dmitrenko, O.; Glukhovstev, M. N. A Theoretical Study of the Effect of a Tetra-Alkylammonium Counterion on the Hydrogen Bond Strength in Z-Hydrogen Maleate. J. Am. Chem. Soc. 2001, 123, 7134-7145.

41. Blades, A. T.; Klassen, J. S.; Kebarle, P. Determination of Ion-Solvent Equilibria in the Gas Phase. Hydration of Diprotonated Diamines and Bis(Trimethylammonium) Alkane. J. Am. Chem. Soc. 1996, 118, 1243712442.

42. Lias, S. G.; Bartmes, J. E.; Liebman, J. F.; Holmes, J. L.; Levin, R. D.; Mallard, W. G. J. Phys. Chem. Ref. Data 1988, 17(Suppl. 1).

43. Maksic, Z B. Kovacevic, B. Towards the Absolute Proton Affinities of $20 \alpha$-Amino Acids. Chem. Phys. Lett. 1999, 307, 497-504. 